\title{
Entrepreneurial Marketing of Small \& Medium Scale Enterprises in a Selected Divisional Secretariat Division of Sri Lanka
}

\author{
K.B.T.U.K. Bandara*, K.A.S.S. Kodithuwakku and V.W. Jayaweera \\ Department of Agricultural Economics \& Business Management, Faculty of Agriculture, University of \\ Peradeniya, Sri Lanka
}

\begin{abstract}
Merging two distinct disciplines, the term Entrepreneurial Marketing (EM) is used to describe the marketing process of small firms pursuing opportunities under limited resource conditions and uncertain market circumstances. The aim of this study was to explore the Entrepreneurial Marketing approach adopted by Small and Medium Scale Enterprises (SMEs) in a selected divisional secretariat division of Sri Lanka. A sample of 90 SMEs was selected using disproportionate stratified random sampling and data were collected using a structured questionnaire. Results revealed that the majority of the SMEs exhibit a moderate level of adoption of EM, while showing the highest and lowest level of adoption towards value creation and innovativeness respectively. Results also revealed that there is a significant relationship between business size, business age and education level of the business operator and the level of adoption of EM. Further, as per the findings, the overall EM and three EM dimensions (value creation, proactiveness and innovativeness) has a positive correlation with the sales growth of the business. Therefore, relevant policy directions and conducting training sessions for SME operators in relation to EM is recommended.
\end{abstract}

Keywords: Entrepreneurial Marketing, EM dimensions, Small and Medium Scale Enterprises

\section{Introduction}

The Small and Medium Enterprise sector (SMEs) has been identified as the backbone of Sri Lankan economy, since it accounts for more than $75 \%$ of the total number of enterprises, provides $45 \%$ of the employment and accounts for $52 \%$ of the Gross Domestic Production (National policy framework for small medium enterprises, 2017). In other words, SME sector can be identified as a driving force for inclusive economic growth, regional development, employment generation and poverty reduction. With the globalization, the SME sector is not merely seen as a sector for "protection and promotion" but, more importantly as a driving force for "growth and development" (National policy framework for small medium enterprises, 2017). Indeed Sri Lankan government tries to develop a conducive environment to micro, small and medium scale start-ups for socio-economic development within the country (Vijayakumar, 2014).

Even though SMEs' role in the economy is vital, many of them are plagued by business failures in terms of bankruptcy and liquidation (Priyanath, 2015). More than 85\%of SMEs face significant survival challenges and more than $75 \%$ fail within five years of start-up (Asian SME Summit, 2009). Hence, the growth and success of SMEs are constrained by problems such as inadequate access to capital and finance, inadequate industrial infrastructure, lack of market-based information, obsolete technology, lack of modern management skills and lack of labour training (Martin, 2009). In this context, Entrepreneurial Marketing (EM) is one of the key determinants of a successful enterprise, since it represents an aggressive and untraditional marketing approach, which provides entrepreneurs with the means to guarantee the success of their business, despite their limited resources (Becherer et al.,2008). 
The concept of entrepreneurial marketing is described as unplanned, nonlinear and visionary marketing activities of the entrepreneur, which is characterized by seven underlying dimensions including, proactiveness, opportunity focus, calculated risk taking, innovativeness, customer intensity, resource leveraging, and value creation (Morris et al., 2002). In fact, such an entrepreneurial perspective helps to enrich the traditional marketing mix and leads to a more entrepreneurial perception of its content ( Kurgun et al., 2011). Indeed, entrepreneurial marketing would be the best approach to eliminate business failures in SME sector and will foster small enterprises to grow into medium sized enterprises and medium sized enterprises to grow into large enterprises (Martin, 2009).

Based on the idea that entrepreneurial marketing is appropriate for small scale enterprises the aim of this study is to explore the Entrepreneurial Marketing approach adopted by small and medium scale enterprises in a selected DS Division of Sri Lanka.

\section{Significance of the study}

In spite of intensive study of business and entrepreneurship, the importance of small business in the social and economic development and the conceptual exploration of EM during past few decades, the lack of attention has been given to the empirical exploration of EM Approach in SME sector. Hence exploring the field of Entrepreneurial Marketing is vital, as there is a dearth of research at the global level and also in the Sri Lankan context.

\section{Literature Review}

\section{Entrepreneurial Marketing}

The concept of entrepreneurial marketing captures the interface between entrepreneurship and marketing (Morris et al., 2002). In fact, the qualities attributed to both entrepreneurship and marketing can be identified in entrepreneurial marketing activities since the EM has been emerged through an entrepreneurial perspective on traditional marketing (Kurgun et al., 2011). With the time, the concept of EM has been defined in different ways by different scholars, since there are many different conceptualizations for entrepreneurship and marketing therein exist.

According to Hill and Wright (2000), EM has been described as the marketing orientation of small firms that is driven and shaped by the owner or manager's personality. According to Morris et al., (2002); EM is the unplanned, non-linear, visionary marketing actions of entrepreneur by proactive identification and exploration of opportunities for acquiring and retaining profitable customers through innovative approaches to risk management, resource leveraging and value creation. Thus EM is a spirit, an orientation as well as a process of pursuing opportunities in growing ventures that create perceived customer value through relationships, especially by employing innovativeness, creativity, selling, market immersion, networking and flexibility (Kurgun et al., 2011). Further, term entrepreneurial marketing is used to describe the marketing processes of small firms pursuing opportunities in uncertain market circumstances and under limited resource conditions (Becherer et al., 2008).

Kotler (2003) has identified entrepreneurial marketing based upon how marketing practices become more formalized. Three stages of marketing practices are identified as organizations grow. EM is related to the first development phase where the level of entrepreneurship is high and the degree of formalization of marketing practices is low. Later and in a more mature stage (second and third stage), marketing practices become formulated marketing. Kotler (2003) stated;“As small companies achieve success, they inevitably move toward more formulated marketing". 


\section{Seven dimensions of Entrepreneurial Marketing}

The study of Morris et al., (2002) established the foundation for the EM literature by introducing the seven dimension framework based on entrepreneurial orientation and marketing orientation. Most of the later researches are based on this model. The dimensions are proactiveness, opportunity driven, resource leveraging, innovativeness, risk management, value creation and customer intensity, and whereas the first five dimensions are related to entrepreneurial orientation and the last two dimensions are related to marketing orientation (Morris et al., 2002).

Proactiveness reflects the firm's orientation towards searching for new ways to acquire a competitive advantage over large scale counterparts, through incremental changes to existing production and marketing practices (Morris et al., 2002). In other words, it involves the actions towards implementing and controlling of new products, services or process before the competitors in the market (Liu et al., 2002). In fact, proactiveness can be identified as the opportunity seeking and forward looking perspective, which involves introducing new products ahead of market competition, which leads to change the marketing environment. Also it has a strong positive relationship with firm's performance and firm's innovative performance as well (Hacioglu et al., 2012).

Opportunity driven is characterized with recognition and pursuit of untapped opportunities regardless of resources under control, which is a main element of entrepreneurship and is a core dimension of EM (Morris et al., 2002). Opportunities reflect the untapped market positions derived from market imperfections, where knowledge about these imperfections and how to exploit them distinguish EM (Hacioglu et al., 2012). In fact, identifying and pursuing market opportunities is critical to success of SMEs and the potential of market opportunities are determined by the degree of fit in relation to resources and capabilities of firm whereas it is the ability of the firm to choose the "right opportunity" at the "right time" (Becherer et al., 2012). Thus, firms should have a creative approach to identify and exploit on untapped market opportunities (Morris et al., 2002).

Entrepreneurial marketing incorporates the dimension of customer intensity as the need for creative approaches to customer acquisition, retention and development (Morris et al., 2002). Moreover, customer intensity is characterized by the attributes of customer equity, visceral relationships and emotional dimension to firm's marketing efforts. In contrast to traditional marketing concepts, this particular dimension of EM is rather important, since it focuses on human relationships and marketing strategies that are more emotional and entrepreneurial in nature (Becherer et al., 2008; Morris et al., 2002).

Entrepreneurial marketing is characterized by risk management or calculated risk taking which represents the overt efforts to recognize the risk factors and then to manage or mitigate those factors (Morris et al., 2002). Under this perspective, entrepreneur tries to identify the elements of external environment which will lead to reduce or eliminate the environment uncertainty, reduce the firm's dependency and vulnerability and to modify the task environment in which the firm operates (Morris et al., 2002). Further, resources are managed in a way that they can be easily converted or used into new projects, thereby enhancing the firm's flexibility. Risk-taking attitudes of owner or operator play a critical role in determining the actions which firm undertake, with entrepreneurs always seeking for risk taking as a part of their job (Becherer et al., 2012).

Innovation represents the firm's ability to create new ideas that are transferrable into new products, services, technologies and markets (Runserspanjol, 2001: cited in Morris et al., 2002). Within the context of EM, the role of innovativeness ranges from opportunity identification, concept generation towards product development and creative augmentation of firm's resources to support innovation. Indeed innovativeness has become pre requisite for SMEs to achieve competitive advantage over their large scale counterparts, since they may not have the adequate resources to meet their industry standards (Hacioglu et al., 2012; Carson and Gilmore, 2000). Moreover, within marketing operations, innovation is ongoing, whereas the managers continually reach towards new marketing approaches in segmentation, branding, pricing, packaging, customer communication, and relationship management etc. (Morris et al., 2002). 
Resource leveraging can be defined as the firm's ability to identify a resource which has not being used optimally, see how the resource could be used in non-conventional ways and convince those that control the resource to let the marketer to use it in a more productive manner (Morris et al., 2002). Hence, entrepreneurial marketers are not constrained by the resources that are currently under their control and they are able to leverage resources in quite different ways such as, using other's resources to accomplish one's own purpose, complementing one resource with another to reach higher combined value, getting use of resources that others haven't realized, using certain resources to obtain other resources and getting use of resources more than others have utilized in the past ( Morris et al., 2002). The most significant form of leveraging is the firms' ability to use other's resources to accomplish marketing goals by adapting to the strategies such as, bartering, borrowing, leasing, renting, sharing, recycling, contracting and outsourcing. Perhaps most of these strategies are accomplished through exchange of favours, social networks and formal initiatives such as strategic alliances and joint ventures (Morris et al., 2002).

Value creation is a process of discovering untapped sources of customer value and to create unique combinations of resources to produce value. It is the marketer's responsibility to identify each marketing mix element in the search of new sources of customer value (Morris et al., 2002). While traditional marketing practices are more focused on transactions and customer relations, the focal point of entrepreneurial marketing is an innovative approach towards value creation (Morris et al., 2002). Perhaps, entrepreneurs are being able to acquire a competitive advantage over their larger scale counterparts, when they discover new ways to create value for customers (Becherer et al., 2012).

\section{Entrepreneurial Marketing approach in the context of Small and Medium Enterprises}

Today the SMEs operate in a rapidly changing environment with a fierce competition and increasingly demanding customers. Further, SMEs more often surface with the conditions including, 1) lack of economies of scale; 2) limited resource in business and marketing; 3) lack of formal organizational structures or formal systems of communication; 4) little market share; 5) a limited market image; 6) decision making under more imperfect conditions than larger firms; 7) limited management skills; 8) a mixture of business and personal goals; 9) limited geographic market presence. Hence, it is widely accepted that the concept of EM is highly appropriate for SMEs in such a context (Jones and Rowley, 2011; Kolabi et al., 2011). Most of the scholars support this idea by defining the EM as a range of marketing actions that SMEs can employ (Becherer et al., 2008).

Entrepreneurial marketing is based on what entrepreneurs do (Stokes, 2000), and therefore has close links to research on SME marketing (Miles and Darroch, 2004). In fact Hill and Wright (2000) has examined the EM and entrepreneurship interface in SMEs, highlighting the entrepreneurial orientation in this particular sector. Moreover, this research highlights the appropriateness of this interface on SMEs and highlighting: the sales and selling focus, marketing skills and competencies, decision making, social networks and marketing planning as the more appropriate EM initiatives for the SME sector.

While some researchers argue that the entrepreneurial marketing activities are related to the entrepreneurial mindset regardless of firm size or age, it is widely accepted that the concept is particularly related to the small business context, since their marketing approaches are not fit with established traditional marketing theories and successful businesses are being able to acquire a competitive advantage on their unique benefit of "smallness" (Jones and Rowley, 2011). Bjerke and Hultman (2002) support to this idea by defining the EM as "Marketing of small firms growing through entrepreneurship"

According to Carson et al., (1995); EM is associated more with small firms than large firms, since established or large firms face stronger internal barriers in reaching towards entrepreneurial marketing approach. Furthermore, decision making in smaller firms is often ad-hoc and they are able to act on opportunities and implement 
strategies faster than larger firms (Morrish and Deacon, 2009). Gorica and Buhaljoti (2016) argue that small firms do not have enough resources to engage in traditional marketing practices. Hence, unlike the larger firms, they practice customization strategies, by putting their efforts on close interactions with customers and build customer loyalty. Kraus et al., (2010) supported to this idea by identifying two perspectives in the definition of entrepreneurial marketing. The first one defines, entrepreneurial marketing as marketing for small or new ventures by emphasizing the quantitative aspect (firm size and age) of the company, and the second one defines entrepreneurial marketing as marketing with an entrepreneurial spirit (marketing by entrepreneurs) by highlighting the qualitative aspect of entrepreneurial marketing.

According to the empirical study of Kilenthong et al., (2015), the level of entrepreneurial marketing practice has a systematic relationship with firm's age. Many scholars have also claimed that, marketing practices in new firms are different from marketing practices in old, established firms. According to Weinrauch et al., (1990), younger or new firms use different marketing strategies than older firms. Hence, Entrepreneurial marketing behaviours are found to be more evident in new firms than older ones (Weinrauch et al., 1990). Thus, new firms' networking activities evolve with firm's age and younger firms use less formal market research than older firms.

Further, according to the empirical study of Kilenthong et al., (2015); there is an impact of firm size on the level of adoption of entrepreneurial marketing whereas the small scale businesses tend to show the highest level of adoption towards EM.

Despite the characteristics of business; the competence of SME operators is also fundamentally important, given their nature and characteristics as well as their dominant role in firm's decision-making process (Carson and Gilmore, 2000). In fact, EM dimensions within SMEs will largely reflect the decisions of the owner or operator of the business (Becherer et al., 2008). Carson and Gilmore (2000) also have investigated on how founder entrepreneurs tend to improve firms' decision-making process, through building their competences and improving their knowledge through experience over time. Further, Krueger and Carsrud (1993) support to this by stating, "Initial choices made by business owners have significant repercussions that persist long after firm emergence". In addition, prior business experience of an entrepreneur influence on how the owner approaches to a new business, whereas entrepreneurs with more business experience are more opportunistic, proactive oriented and use leverage strategies more frequently (Bercherer et al., 2008)

As SMEs tend not to employ specialists, most management decisions are taken by business owners, and they are pretend to become "generalists" undertaking a wide range of business activities. In turn, this implies that SMEs are also significantly characterized by the personality and management style of the entrepreneur (Stokes, 2000). Franco et al., (2014) has identified that entrepreneurial experience, skills, attitudes, and knowledge of marketing as key characteristics of entrepreneur which influence on firm's level of adoption towards EM approach. In fact, the business owner plays a crucial role in orienting entrepreneurial marketing in SMEs, and this may reflect how passionate the entrepreneur is about the business (Franco et al., 2014). Hence, entrepreneurial marketing activities can be strongly influenced by the characteristics of the founder-entrepreneur; gender, level of business experience and the level of knowledge (Krueger and Carsrud, 1993)

Further Becherer et al.,(2012) investigated on the effect of EM on outcome goals of SMEs and the results of the study revealed that the four EM dimensions of value creation, proactiveness, innovativeness and customer intensity are having a significant and positive impact on overall company performance, whereas the dimension of value creation has the significant and positive impact on both growth goals and return goals. Thus, most of the researchers have identified EM behaviours in high growth firms. 


\section{Conceptual Framework}

According to the reviewed literature the conceptual framework was developed as depicted in figure 1.1.

\begin{tabular}{|l|}
\hline Characteristics of business owner \\
-Gender \\
-Age \\
-Religion \\
-Level of education \\
-Level of business experience \\
\end{tabular}

Characteristics of business

-Size of business

(Small vs medium)

-Age of business

(New vs old)

-Type of business

-Type of Industry(Manufacturing, Service , Retailing)

\section{Level of adoption of Entrepreneurial Marketing} Approach

Proactiveness

Innovativeness

Calculated risk taking

Opportunity focus

Resource leveraging

Customer intensity

Value creation

Figure 1

\section{Hypotheses}

H1 - There is a relationship between type of industry and the level of adoption of EM

$\mathrm{H} 2$-There is a relationship between business size (small vs medium) and the level of adoption of EM

H3- There is a relationship between business age (New \& small) and the level of adoption of EM

H4- There is a relationship between business type and the level of adoption of EM

H5- There is a relationship between age and the level of adoption of EM 
H6-There is a relationship between gender and the level of adoption of EM

H7-There is a relationship between education and the level of adoption of EM

H8-There is a relationship between business experience and level of adoption of EM

H9- There is a relationship between religion and level of adoption of EM

H10-There is a relationship between EM \& perceived sales growth of businesses

\section{Methodology}

\section{Research Goals}

In this survey, we aim to identify the level of adoption of EM of SMEs, the factors affecting the level of adoption of EM and the relationship between EM and sales growth of businesses. To test the propositions, a field survey using questionnaires was conducted.

\section{Measures}

The constructs in this study were developed based on measurement scales adopted from prior studies. Basically, characteristics of business (business size, business age, type of business, type of industry) and characteristics of business owner (Age, gender, religion, level of education, level of business experience) were considered as independent variables (Table 1.1). The level of adoption of EM was considered as dependent variable and it was measured using five-point Likert scale ranging from $1=$ strongly disagree to $5=$ strongly agree. Items for measuring Entrepreneurial Marketing were adopted from the study of Fiore et al., (2013). This scale consists of seven dimensions, namely Proactiveness (5 items), Opportunity Focus (5 items), Calculated Risk Taking (3 items), Innovativeness (5 items), Customer Intensity (3 items), Resource Leveraging ( 7 items) and Value Creation (4 items) as depicted in table 1.2.

Table 1.1 Operationalization of Independent variables

\begin{tabular}{|c|c|c|}
\hline Variable & Measure & Scale \\
\hline \multirow[t]{2}{*}{ Gender } & Male & Nominal \\
\hline & Female & \\
\hline \multirow[t]{5}{*}{ Age ( In years) } & below 20 & Interval \\
\hline & $20-30$ & \\
\hline & $31-40$ & \\
\hline & $41-50$ & \\
\hline & $51-60$ & \\
\hline \multirow[t]{6}{*}{ Level of education } & Above 60 & Ordinal \\
\hline & Up to Ordinary Level(O/L) & \\
\hline & $\mathrm{O} / \mathrm{L}$ Passed & \\
\hline & Advanced Level Passed(A/L) & \\
\hline & Diploma & \\
\hline & Graduate & \\
\hline \multirow[t]{3}{*}{ Level of business experience } & Less than 1 year & Interval \\
\hline & $1-5$ years & \\
\hline & 6 to 10 years & \\
\hline
\end{tabular}




\begin{tabular}{lll}
\hline \multirow{3}{*}{ Size of business } & more than 10 years & Nominal \\
& Small scale & \\
Age of business & Medium scale & Interval \\
& Less than 5 years & \\
Type of Industry & 5 or more than 5 years & Nominal \\
& Manufacturing & \\
Type of business & Service & Nominal \\
& Retailing & \\
& Sole proprietorship & \\
& Partnership & \\
\hline
\end{tabular}

Table 1.2 Operationalization of seven EM dimensions

\begin{tabular}{|c|c|c|}
\hline EM dimension & Measures & Scale \\
\hline Proactiveness & $\begin{array}{l}\text { Continuously changing the way of marketing, the products in the business } \\
\text { Action oriented than reaction oriented } \\
\text { Consistently monitoring \& improving the marketing of business } \\
\text { Enjoy overcoming business obstacles } \\
\text { Turning business ideas into reality }\end{array}$ & $\begin{array}{l}\text { Five-point } \\
\text { likert }\end{array}$ \\
\hline Risk Management & $\begin{array}{l}\text { Entering to new marketing direction, in stages rather than all at once } \\
\text { Using creative, low cost way to reduce risks associated with new marketing } \\
\text { activities } \\
\text { Risk taking to pursue opportunities }\end{array}$ & $\begin{array}{l}\text { Five-point } \\
\text { likert }\end{array}$ \\
\hline Opportunity driven & $\begin{array}{l}\text { Ability to react for the new market opportunities which arise in the market } \\
\text { Excels at identifying market opportunities } \\
\text { Looking for business opportunities beyond the current markets/or current } \\
\text { customers } \\
\text { Looking for new opportunities } \\
\text { Regularly pursuing market opportunities regardless of resource constraints }\end{array}$ & $\begin{array}{l}\text { Five-point } \\
\text { likert }\end{array}$ \\
\hline Innovativeness & $\begin{array}{l}\text { Communicating with customers to identify innovation opportunities } \\
\text { Innovation is the key to achieve competitive advantage in business } \\
\text { Staff contribution towards innovations undertaken by the business } \\
\text { Use of innovative approaches to makes the business activities more } \\
\text { efficient } \\
\text { Existence of an atmosphere which encourages the innovativeness within } \\
\text { the business }\end{array}$ & $\begin{array}{l}\text { Five- } \\
\text { pointlikert }\end{array}$ \\
\hline Resource leveraging & $\begin{array}{l}\text { Always find ways to acquire the resources, need to get the job done } \\
\text { Business is performing high with less resources } \\
\text { Using networks to get advantage in favor of business } \\
\text { Complementing one resource with another to create higher combined value } \\
\text { Use existing resources to control other resources } \\
\text { Use certain resources to obtain other resources Eg: Leasing, renting, } \\
\text { recycling } \\
\text { Ability to use other people's(or firm's) resources to accomplish one's own } \\
\text { purpose }\end{array}$ & $\begin{array}{l}\text { Five-point } \\
\text { likert }\end{array}$ \\
\hline
\end{tabular}




\begin{tabular}{lll}
\hline Customer intensity & Ability to create solid relationships with customers & $\begin{array}{l}\text { Five- } \\
\text { pointlikert }\end{array}$ \\
& Spending resources on identifying customers & Attention towards the customer satisfaction \\
Value creation & Expecting every employee to be looking for ways in creating more value & $\begin{array}{l}\text { Five- } \\
\text { pointlikert }\end{array}$ \\
& Create value for customers with excellent customer service & \\
& Attention towards the pricing structure which enables creating value for \\
& customers & \\
& Identification methods of creating value for customers & \\
\hline
\end{tabular}

\section{Sample and Data collection}

Small and Medium enterprise (SMEs) operators those who registered under the Anuradhapura divisional secretariat division were treated as the population and disproportionate stratified random sampling method was adopted to select a sample of 90 SME operators from the three industries including; Manufacturing, Service and Retailing consisting 30 SMEs from each. Response rate was $97.78 \%$ as out of 90 SMEs, two respondents declined to respond to the questionnaire. The hypothesized relationships were tested with data collected through pre tested structured questionnaires administered as face-to-face interviews to SME operators in the study area.

\section{Methods of Data Analysis}

For the purpose of data analysis, the Statistical Software Package of SPSS Version 20 was used to analyze all the data gathered from the questionnaire. The techniques of analysis used in this study is depicted in the below table 1.3 .

Table 1.3 Methods of Data Analysis

\begin{tabular}{ll}
\hline & Analytical Methods \\
\hline Internal consistency of EM scale & Cronbach's alpha Reliability Test \\
Normality Test & Kolmogorov-Sminrov Test \\
$\begin{array}{ll}\text { To assess the level of adoption of EM and each EM } \\
\text { dimensions of SMEs }\end{array}$ & $\begin{array}{l}\text { EM Index } \\
\text { Descriptive statistics }\end{array}$ \\
$\begin{array}{l}\text { To identify the factors affecting the level of adoption } \\
\text { of EM }\end{array}$ & $\begin{array}{l}\text { Ordered Logistic Regression } \\
\text { Relationship between EM and growth of business }\end{array}$ \\
\end{tabular}

\section{Results \& Discussion}

\section{Demographic and Personal Characteristics of the Sample}

A brief summary on characteristics of business (Business age, business size, type of the business entity and type of industry) and the personal characteristics of owner or operator of the business (Gender, age, religion, highest level of education, business experience etc.) is depicted in the below table 1.4. The sample of the study is 
comprised of 88 SMEs from three industries including, manufacturing (28), service (33) and retailing (27). Response rate was $97.78 \%$ as out of 90 SMEs, two respondents declined to respond to the questionnaire

Table 1.4: Descriptive statistics of the demographic and personal characteristics of the sample

Personal/ Demographic
Demographic characteristics of business

Industry

Manufacturing

Service

Retailing

Size of the business

Small

Medium

Growth rate of the business ( Sales growth of year 2018, compared to 2017)

Decrease

Stable

Increase

Age of the business

Newly established $(<5$ years $)$

Old $(>=5$ years

28

33

27

19

46

36

52

Type of the business entity

Sole proprietorship

Partnership

Private Limited company
31.8

37.5

30.7

63.6

36.4

26.1

21.6

52.3

40.9

59.1
90.9

9.1

5.7

36.4

28.4

21.6

8

92

2.3

5.7

Business experience

Less than 1 year

1 to 5 years 
6 to 10 years 28

Highest level of education

$\begin{array}{lll}\text { Up to O/L } & 3 & 3.4 \\ \text { O/L Passed } & 14 & 15.9 \\ \text { A/L Passed } & 42 & 47.7 \\ \text { Diploma } & 14 & 15.9 \\ \text { Graduate } & 15 & 17\end{array}$

\section{Level of adoption of EM approach by SMEs in the study area}

In this study, SMEs' level of adoption of EM approach was assessed using Entrepreneurial Index (EMI) developed based on the EBI index of Balasaravanan \& Vijayadurai (2012). Further descriptive statistics were used to elaborate more on the overall level of adoption towards EM by SMEs as mentioned in the below table 1.5 .

$$
\mathrm{EMI}=\frac{\sum_{i=1}^{n} S E V_{i}}{\sum_{i=1}^{n} M S E V_{i}} \times 100
$$

SEV - Score on level of adoption of EM MSEV - Maximum score on level of EM $\mathrm{i}=1-\mathrm{n}$ - number of statements in EM scale

Table 1.5; Descriptive statistics of overall level of adoption of EM by sample respondents

\begin{tabular}{cccccc}
\hline & $\mathrm{N}$ & Min & Max & Mean & SD \\
\hline Level of adoption of EM & 88 & 54.29 & 99.05 & 72.42 & 7.55 \\
\hline
\end{tabular}

Based on the levels of adoption of EM; the SMEs in the sample were grouped into 3 categories as Poorly adopted, Moderately adopted and Highly adopted as depicted in the Table 1.6.

Table 1.6: Classification of SMEs based on the level of adoption of EM

\begin{tabular}{llll}
\hline Level of adoption of EM & Criterion based on the EMI & Number of SMEs & Percentage of SMEs \\
\hline Poorly adopted & $<($ Mean - SD) & 10 & 11.4 \\
& $<64.87263 \%$ & & 70.5 \\
Moderately adopted & $($ Mean - SD) $-($ Mean + SD) & 62 & \\
& $64.87263-79.97577$ & &
\end{tabular}




\begin{tabular}{llll}
\hline Highly adopted & $>($ Mean + SD $)$ & 16 & 18.2 \\
& $>79.97577 \%$ & &
\end{tabular}

As depicted in table 1.6; majority of the SMEs in the sample (70.5\%) fall within the moderate level of adoption of EM, and SMEs fall within highly adopted (18.2\%) and poorly adopted (11.4\%) groups were comparatively smaller.

Further, the results of cross tabulation (As depicted in Table 1.7) revealed that, majority of the respondents (SME operators) in the poorly adopted group are within the age group of 31 to 40 , passed up to A/Ls and operating in small scale old businesses in retailing sector. In addition, majority of these SMEs are having decreasing sales growth $(50 \%)$. Moderately adopted group is dominated by the entrepreneurs whose age is within 31-40 years, have passed up to A/Ls and operates small scale businesses. Their businesses are old and they predominantly operate in service sector. Majority of the respondents in highly adopted group are within the age categories of 31-40 and 41-50 and majority of them are graduates who operates in medium scale businesses. In addition, majority of these businesses are newly established businesses in service sector. Furthermore, 68.6\% of them maintain increasing sales growth.

Table 1.7; Results of Cross Tabulation

\begin{tabular}{|c|c|c|c|c|}
\hline \multirow[t]{2}{*}{ Demographic variable } & \multirow[t]{2}{*}{ Categories of each variable } & \multicolumn{3}{|c|}{ Percentage of SMEs in each category } \\
\hline & & Poor & Moderate & High \\
\hline \multirow[t]{2}{*}{ Business size } & Small & $90^{*}$ & $64.5^{*}$ & 43.8 \\
\hline & Medium & 10 & 35.5 & $56.2^{*}$ \\
\hline \multirow[t]{2}{*}{ Business age } & Less than 5 years & 10 & 41.9 & $56.2^{*}$ \\
\hline & 5 or more than 5 years & $90 *$ & $58.1^{*}$ & 43.8 \\
\hline \multirow[t]{3}{*}{ Industry } & Manufacturing & 20 & 33.9 & 31.2 \\
\hline & Service & 30 & $37.1 *$ & $43.8^{*}$ \\
\hline & Retailing & $50^{*}$ & 29.0 & 25.0 \\
\hline \multirow[t]{3}{*}{ Growth of the business } & Decrease & $50 *$ & 25.8 & 12.5 \\
\hline & Stable & 30 & 24.2 & 18.8 \\
\hline & Increase & 20 & $50.0^{*}$ & $68.6^{*}$ \\
\hline \multirow[t]{5}{*}{ Age of the owner } & $20-30$ & 0 & 4.8 & 12.5 \\
\hline & $31-40$ & 40 & 37.1 & 31.2 \\
\hline & $41-50$ & 10 & 30.6 & 31.2 \\
\hline & $51-60$ & 30 & 21.0 & 18.8 \\
\hline & above 60 & 20 & 6.5 & 6.2 \\
\hline \multirow{4}{*}{$\begin{array}{l}\text { Highest level of } \\
\text { education }\end{array}$} & Up to $\mathrm{O} / \mathrm{L}$ & 10 & 3.2 & 0 \\
\hline & $\mathrm{O} / \mathrm{L}$ Pass & 10 & 21.0 & 0 \\
\hline & $\mathrm{A} / \mathrm{L}$ Pass & $60^{*}$ & $48.4^{*}$ & $37.5^{*}$ \\
\hline & Diploma & 10 & 14.5 & 25.0 \\
\hline
\end{tabular}




\section{Graduate} 10 12.9 $37.5^{*}$

In addition, descriptive statistics were used to explore the SMEs' level of adoption of each of the EM dimensions as mentioned in table 1.8.

Table 1.8: Descriptive statistics of seven EM dimensions

\begin{tabular}{lllll}
\hline EM dimension & Mean & Min & Max & SD \\
\hline & & & & 100.58 \\
Proactiveness & 74.69 & 50.00 & 100.00 & 10.98 \\
Risk Management & 74.70 & 26.67 & 100.00 & 11.94 \\
Opportunity driven & 69.82 & 40.00 & 96.67 & 12.59 \\
Innovativeness & 67.42 & 40.00 & 100.00 & 10.17 \\
Resource leveraging & 69.17 & 33.33 & 97.14 & 9.09 \\
Customer intensity & 74.19 & 57.14 & 100.00 & 8.10 \\
Value creation & 76.04 & 54.29 & & \\
\hline
\end{tabular}

As depicted in table 1.8, SMEs in the sample of study showed the highest level of adoption towards value creation which is $76.04 \%$, and the lowest level of adoption towards innovativeness which is $67.42 \%$ out of each EM dimensions.

\section{Factors affecting the level of adoption of EM}

Ordered logistic regression was used to determine the factors affecting the level of adoption of EM by SMEs. The level of adoption of EM was considered as dependent variable and characteristics of business (business size, business age, type of business), characteristics of business owner and the type of industry (manufacturing, service, retailing/ wholesale) were considered as independent variables. The regression model used for the study is given below.

$$
\begin{aligned}
& Y=\beta_{0}+\beta_{1} X_{1}+\beta_{2} X_{2}+\beta_{3} X_{3}+\beta_{4} X_{4}+\beta_{5} X_{5}+\beta_{6} X_{6}+\beta_{7} X_{7}+\beta_{8} X_{8}+\beta_{9} X_{9}+\beta_{10} X_{10}+U \\
& \mathrm{Y}=\text { Level of adoption of EM } \\
& \mathrm{X}_{1} \text {-Type of Industry } \quad \mathrm{X}_{6} \text {-Business Experience } \\
& \text { U-Random Error } \\
& \mathrm{X}_{2} \text {-Age } \quad \mathrm{X}_{7} \text {-Business size } \\
& \mathrm{X}_{3} \text {-Gender } \quad \mathrm{X}_{8} \text { - Business age } \\
& \mathrm{X}_{4} \text {-Religion } \quad \mathrm{X}_{9} \text { - Business type } \\
& \text { X5-Education } \quad \beta 1, \beta 2, \beta 3 \ldots \text { - Coefficients of estimation }
\end{aligned}
$$

As depicted in table 1.9 Pseudo $\mathrm{R}$ Square is 0.383 , which shows that the independent variables included in the model explain $38.3 \%$ of the variation in the dependent variable. Also $p$ value (0.046) shows that the model is significant $(\mathrm{p}<0.05)$. 
Table 1.9: Model Summary

\begin{tabular}{lllc}
\hline Model & Pseudo & \multicolumn{2}{l}{ Statistics of model fitness } \\
\cline { 3 - 4 } & R2 & Chi-square & $\mathrm{p}$ \\
\hline 1 & 0.383 & 32.153 & 0.046 \\
\hline
\end{tabular}

Table 1.10: Regression results of determinants of EM.

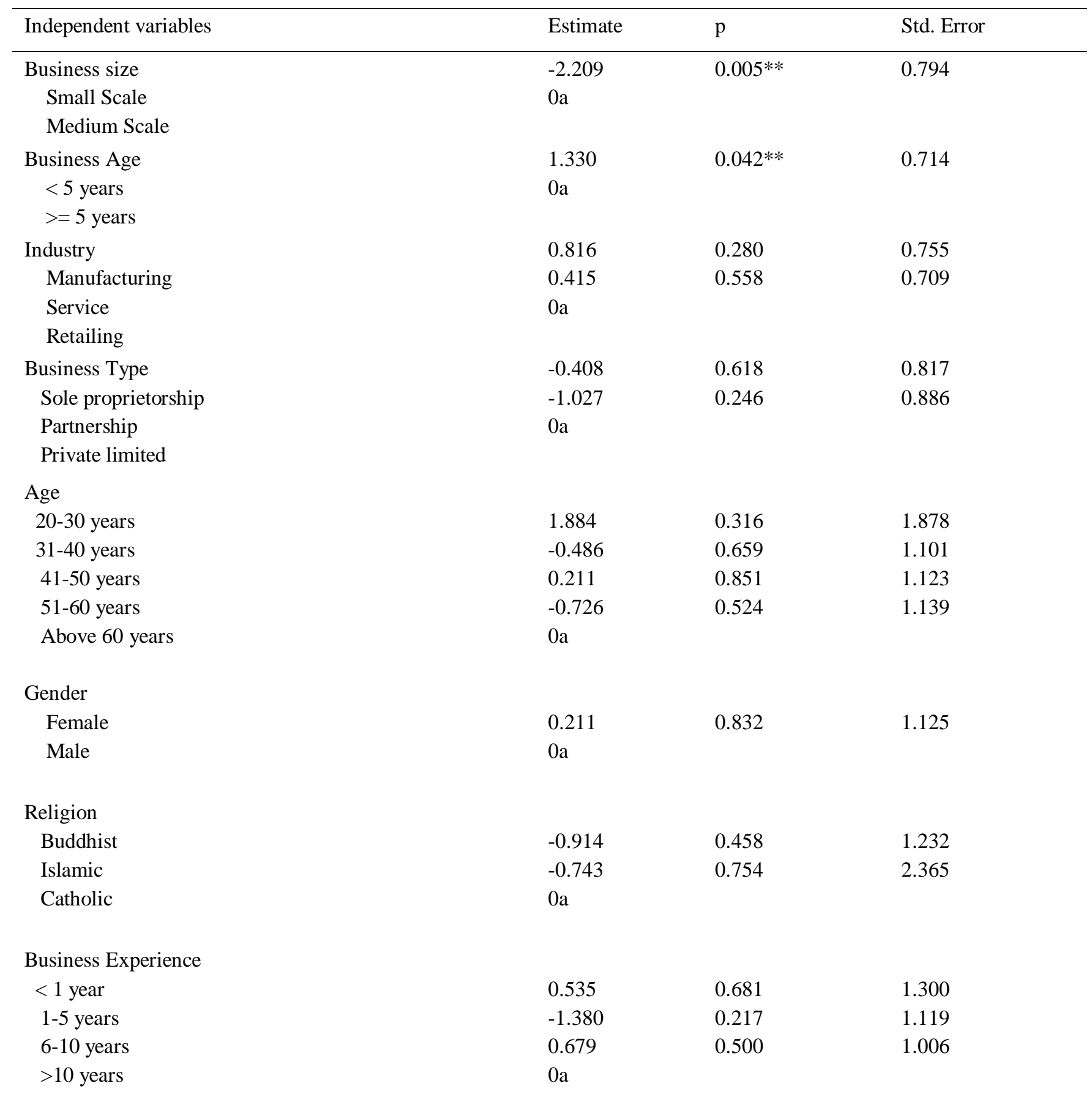


Level of Education

Up to Ordinary Level(O/L)

0.087*

1.839

O/L Passed

$-1.448$

0.095*

1.161

Advanced level (A/L) Passed

$-0.973$

0.249

0.845

Diploma

0.729

0.472

1.015

Graduate

0a

Further, results of regression analysis (as depicted in table 1.10) suggested; business age ( $<<0.05)$, business size $(p<0.05)$, and the level of education of business owner $(p<0.1)$, are the statistically significant factors which effect on the level of adoption of EM by SMEs in the sample profile. Thus, most of the independent variables which describe the characteristics of the business owner do not affect the level of adoption of EM ( Ex: Age, gender, religion, level of business experience of business owner).

In fact, estimates of the regression analysis revealed that medium scale businesses tend to show higher level of adoption of EM compared with the small scale businesses and newly established businesses tend to show the higher level of adoption of EM compared with old established businesses. Moreover, this result is supported by previous research studies of Weinrauch et al.,(1990), Gruber (2004) and Kilenthong et al., (2015). Thus according to Kilenthong et al., (2015), new firms' networking activities evolve as firms' age and they tend to use less of formal market research than older firms, which lead to show a higher level of adoption of EM, compared to old established firms. Further, entrepreneurs with high level of education tend to show higher level of adoption of EM

\section{Relationship between EM and sales growth of SMEs}

Relationship between EM approach and sales growth of the business were tested using Pearson correlation. Supporting the previous literature (Bercherer et al., 2012) according to the findings there is a significant relationship between EM and the sales growth of the businesses. Also results revealed that the three EM dimensions of value creation, proactiveness and innovativeness are having a significant and positive correlation with sales growth of business. These results are in line with the results of the study of Bercherer et al., (2012).

Table 1.11; Results of correlation test of EM dimensions and the sales growth of business

\begin{tabular}{lll}
\hline & \multicolumn{2}{l}{ Sales Growth } \\
\cline { 2 - 3 } & Pearson correlation & Sig(p) \\
\hline Overall EM & 0.215 & $0.045^{*}$ \\
Proactiveness & 0.344 & $0.001^{*}$ \\
Risk Management & 0.051 & 0.634 \\
Opportunity driven & 0.126 & 0.242 \\
Innovativeness & 0.229 & $0.032^{*}$ \\
Risk Management & 0.015 & 0.893 \\
Customer intensity & 0.020 & 0.851 \\
Value creation & 0.180 & $0.093 * *$ \\
\hline
\end{tabular}




\section{Conclusion}

Based on the idea that entrepreneurial marketing is seen appropriate for small and medium scale enterprises, the survey examined the level of adoption of EM by SMEs, factors affecting the level of adoption of EM and the relationship between EM and sales growth of SMEs. Data were collected through administered structured questionnaire survey using 90 business operators in Anuradhapura DS division of Sri Lanka. Results suggested that majority of the SMEs exhibit a moderate level of adoption of EM, while showing the highest level of adoption towards value creation and the lowest level towards innovativeness.

Further, the findings exhibited that business size, business age and the level of education of business owner are the statistically significant factors which effect on the level of adoption of EM. In fact, medium scale businesses tend to show higher level of adoption of EM compared with the small scale businesses and newly established businesses tend to show the higher level of adoption of EM compared with old established businesses. Thus, it can be argued that new firms' networking activities evolve as firms' age and they tend to use less of formal market research than older firms, which lead to show a higher level of adoption of EM, compared to old established firms.

The results also revealed that overall EM and the three EM dimensions of value creation, proactiveness and innovativeness are having a significant and positive correlation with the sales growth of businesses.

Considering the results of the study in to account it can be recommended to the relevant authorities of the country to conduct training sessions for SMEs in relation to EM practices with special attention towards poorly adopted dimensions of EM (Innovativeness, Resource leverage and Opportunity driven) which were identified by this research.

Nevertheless, this study was limited to a single DS division of Sri Lanka and it is recommended that further researches can be conducted to cover the whole country for the generalizability of findings. Also, further researches can be designed to explore relationship between entrepreneurial marketing and other performance indicators such as firm's innovative performance and customer performance etc.

\section{References}

Asian SME Summit, 2009, Public Private Partnership in SME Development through Capacity Building, Policy \& Research., http://www.philippinechamber.com/index.php.

Balasaravanan, K. and Vijayadurai, J.,(2012). Entrepreneurial Behavior among Farmers-An empirical Study. International Journal of Exclusive Management Research, 2(1), pp.1-11.

Becherer, R.C., Haynes, P.J. and Helms, M.M., 2008. An exploratory investigation of entrepreneurial marketing in SMEs: The influence of the owner/operator. Journal of Business and Entrepreneurship, 20(2), p.44.

Becherer, R.C., Helms, M.M. and McDonald, J.P., 2012. The effect of entrepreneurial marketing on outcome goals in SMEs. New England Journal of Entrepreneurship, 15(1), pp.7-18.

Bjerke, B. and Hultman, C., 2002. Entrepreneurial marketing: The growth of small firms in the new economic era. Edward Elgar Publishing.

Carson, D., Cromie, S., McGowan, P. and Hill, J., 1995. Marketing and entrepreneurship in SMEs: an innovative approach. Pearson Education

Carson, D. and Gilmore, A., 2000. Marketing at the interface: not 'what'but 'how'. Journal of marketing theory and practice, $8(2)$, pp.1-7.

Culture, E. (2015) 'National Policy Framework for Small and Medium (SME) Development', pp. 1-13.

Dasanayaka, S.W.S.B., Kankanamge, R. and Sardana, G.D., 2011. Identification of barriers for development of the Sri Lankan small and medium scale furniture and wooden products manufacturing enterprises, a case study based on the moratuwa AREA. Euro Asia Journal of Management, 21(40). 
Fiore, A.M., Niehm, L.S., Hurst, J.L., Son, J. and Sadachar, A., 2013. Entrepreneurial marketing: Scale validation with small, independently-owned businesses. Journal of Marketing Development and Competitiveness, 7(4), p.63.

Franco, M., de Fátima Santos, M., Ramalho, I. and Nunes, C., 2014. An exploratory study of entrepreneurial marketing in SMEs: The role of the founder-entrepreneur. Journal of Small Business and Enterprise Development, 21(2), pp.265-283.

Gorica, K. and Buhaljoti, A., (2016). Entrepreneurial Marketing: Evidence from SMEs in Albania. American Journal of Marketing Research, 2(2), pp.46-52

Hacioglu, G. et al. (2012) 'The Effect of Entrepreneurial Marketing on Firms' Innovative Performance in Turkish SMEs', Procedia - Social and Behavioral Sciences, 58, pp. 871-878.

Hill, J. and Wright, L.T., 2000. Defining the scope of entrepreneurial marketing: a qualitative approach. Journal of Enterprising Culture, 8(01), pp.23-46.

Jayasekara, J.P.D.R. and Thilakarathna, A., (2013) Government Policy and Strategy for SME Development. In The 4th IMF-Japan High-Level Tax Conference for Asian Countries.

Jones, R. and Rowley, J. (2011) 'Entrepreneurial marketing in small businesses: A conceptual exploration', International Small Business Journal, 29(1), pp. 25-36.

Kilenthong, P., Hills, G. E. and Sclove, S. L. (2015) 'Entrepreneurial Marketing Practice: Systematic Relationships with Firm Age, Firm Size, and Operator's Status', International symposium on marketing \& entrepreneurship, pp. 1-15.

Kolabi, A.M., Hosseini, H.K., Mehrabi, R. and Salamzadeh, A., 2011. Developing entrepreneurial marketing mix: Case study of entrepreneurial food enterprises in Iran. Journal of Knowledge Management, Economics and Information Technology, 5, pp.1-17.

Kottler, P., 2003. Marketing Insights from A to Z. John Willey and Sons Inc. Hoboken.

Kraus, S., Harms, R. and Fink, M., 2010. Entrepreneurial marketing: moving beyond marketing in new ventures. International Journal of Entrepreneurship and Innovation Management, 11(1), pp.19-34.

Kropp, F., Lindsay, N.J. and Shoham, A., 2008. Entrepreneurial orientation and international entrepreneurial business venture startup. International Journal of Entrepreneurial Behavior \& Research, 14(2), pp.102-117.

Krueger, N.F. and Carsrud, A.L., 1993. Entrepreneurial intentions: applying the theory of planned behaviour. Entrepreneurship \& Regional Development, 5(4), pp.315-330.

Kurgun, H. et al. (2011) 'Entrepreneurial Marketing-The Interface between Marketing and Entrepreneurship: A Qualitative Research on Boutique Hotels; European Journal of Social Sciences ISSN European Journal of Social Sciences , 26(3), pp. 1450-2267.

Liu, X., Xiao, W. and Huang, X., 2002. Bounded entrepreneurship and internationalisation of indigenous Chinese private-owned firms. International Business Review, 17(4), pp.488-508.

Martin, D.M., (2009) The entrepreneurial marketing mix. Qualitative Market Research: An International Journal, 12(4), pp.391-403.

Miles, M., Gilmore, A., Harrigan, P., Lewis, G. and Sethna, Z., 2015. Exploring entrepreneurial marketing. Journal of Strategic Marketing, 23(2), pp.94-111.

Miles, M.P. and Darroch, J., 2006. Large firms, entrepreneurial marketing processes, and the cycle of competitive advantage. European journal of marketing, 40(5/6), pp.485-501.

Morris, M.H., Schindehutte, M. and LaForge, R.W., 2002. Entrepreneurial marketing: a construct for integrating emerging entrepreneurship and marketing perspectives. Journal of marketing theory and practice, 10(4), pp.1-19

Morrish, S. C. (2011) 'Entrepreneurial marketing: A strategy for the twenty-first century; Journal of Research in Marketing and Entrepreneurship, 13(2), pp. 110-119. doi: 10.1108/14715201111176390.

Najib, M. and Kiminami, A., 2011. Innovation, cooperation and business performance: Some evidence from Indonesian small food processing cluster. Journal of Agribusiness in Developing and Emerging Economies, 1(1), pp.75-96.

Pallant, J., 2013. SPSS survival manual: A step by step guide to data analysis using IBM SPSS. London: McGraw-Hill 
Philip, M., 2011. Factors affecting business success of small \& medium enterprises (SMEs). Amity Global Business Review, 6(1), pp.118-136.

Prasad, V.N., 2004. Strengthening policies through international cooperation. Sweden: IKED/INSME International Roundtable.

Priyanath, H.M.S. and Premaratne, S.P., 2015. Government SME Development Programs in Sri Lanka: A Review in the Lens of Transaction Cost Economics. Sabaragamuwa University Journal, 13(2).

Scarborough, N.M. and Zimmerer, T.W., 1984. Effective Small Business Management, Charles E. Merrill, Columbus, $\mathrm{OH}$.

Schmid, J., 2012. Entrepreneurial Marketing-Often Described, Rarely Measured: A Proposal for An Operationalization of Entrepreneurial Marketing in SMEs Based on Established Frameworks in The Literature. In Academy of Marketing Conference, Southampton, 02 (Vol. 5).

Sekaran, U., 2008. Research Methods for Business: A Skill-Building Approach. New York: John Wiley \& Sons Inc.

Stokes, D., 2000. Entrepreneurial marketing: a conceptualisation from qualitative research. Qualitative market research: an international journal, 3(1), pp.47-54.

Stokes, D., 2000. Putting entrepreneurship into marketing: the processes of entrepreneurial marketing. Journal of research in marketing and entrepreneurship, 2(1), pp.1-16.

Stokes, D., and Wilson, N., 2010. Small business management and entrepreneurship. Cengage Learning EMEA.

Vijayakumar, S., 2014. The status of small and medium enterprises and promotions for their growth in Sri Lanka. International Journal on Global Business Management and research, 1(2), pp.1-12.Hisrich, R.D. and Brush, C., 1986. Characteristics of the minority entrepreneur. Journal of Small business management, 24 , p.1.

Weinrauch, J., Pharr, J., Mann, K. and Robinson, P., 1990. An exploratory survey of low-cost marketing strategies and techniques among selected small business owners: research opportunities and implications". Research at the Marketing/Entrepreneurship Interface, University of Illinois at Chicago, Chicago, IL, pp.122136.

Whalen, P.S. and Akaka, M.A., 2016. A dynamic market conceptualization for entrepreneurial marketing: the co-creation of opportunities. Journal of Strategic Marketing, 24(1), pp.61-75.

Zimmerer, T.W. and Scarboroug, N.M., 2005. Essentials of entrepreneurship and small business management. Prentice-Hall 


\section{Appendices}

\section{Appendix 01}

\section{Questionnaire of the Survey}

\section{A Study of Entrepreneurial Marketing of SMEs in Anuradhapura DS Division}

\section{Instructions; Please tick (x) your answer on the following questions/statements}

Section 01- Background information of business and owner of business

\begin{tabular}{|l|l|l|l|l|}
\hline 01 & Gender & Male & & Female \\
\hline
\end{tabular}

\begin{tabular}{|l|l|l|l|l|l|}
\hline 02 & Age in years & Below 20 & $41-50$ & \\
\cline { 3 - 5 } & $20-30$ & & $51-60$ & \\
\hline & $31-40$ & & Above 60 & \\
\hline
\end{tabular}

\begin{tabular}{|l|l|l|l|l|l|}
\hline 03 & Religion & Buddhist & & Catholics & \\
\cline { 3 - 5 } & Hindu & & Other (please specify) & \\
\cline { 3 - 6 } & Islamic & & & \\
\hline
\end{tabular}

\begin{tabular}{|l|l|l|l|l|l|}
\hline 04 & Highest Level of education & Upto O/L & & Undergraduate & \\
\cline { 3 - 5 } & & O/L Passed & & Graduate & \\
\cline { 3 - 5 } & A/L Passed & & Other specify & \\
\cline { 3 - 5 } & Diploma & & & \\
\hline
\end{tabular}

\begin{tabular}{|c|c|c|c|}
\hline \multirow[t]{2}{*}{06} & \multirow{2}{*}{ Business experience } & Less than 1 year & 5 to 10 years \\
\hline & & 1 to 5 years & More than 10 years \\
\hline
\end{tabular}

\begin{tabular}{|l|l|l|l|l|l|}
\hline 07 & Business size............ & $1-10$ employees & & $51-100$ employees & \\
\cline { 3 - 6 } & & $11-50$ employees & & More than 100 & \\
\hline
\end{tabular}

\begin{tabular}{|c|c|c|c|}
\hline 08 & Age of the business & Less than 5years & 5 or more than 5 years \\
\hline
\end{tabular}

\begin{tabular}{|l|l|l|l|l|l|}
\hline 09 & Industry & Manufacturing & & Retailing/ Wholesaling & \\
\hline
\end{tabular}




\begin{tabular}{|l|l|l|l|l|}
\hline & Service & & & \\
\hline
\end{tabular}

\begin{tabular}{|c|c|c|c|}
\hline \multirow[t]{3}{*}{10} & \multirow{3}{*}{$\begin{array}{l}\text { Growth rate ( annual sales } \\
\text { growth) }\end{array}$} & Decrease & Increase by $10 \%-50 \%$ \\
\hline & & Stable & Increase by more than $50 \%$ \\
\hline & & $\begin{array}{l}\text { Increase by less than } \\
10 \%\end{array}$ & \\
\hline
\end{tabular}

\begin{tabular}{|l|l|l|l|l|l|}
\hline 11 & Type of business entity & Sole proprietorship & & Private Limited company & \\
\cline { 3 - 5 } & & Partnership & & & \\
\hline
\end{tabular}

(Put ;1-Strongly disagree, 2-Disagree, 3-Neutral, 4- Agree,5-Strongly agree)

\begin{tabular}{|c|c|c|c|c|c|c|}
\hline \multicolumn{7}{|c|}{ Section 02- A)Proactiveness (Q1- Q8) } \\
\hline & Statement & 1 & 2 & 3 & 4 & 5 \\
\hline 01 & $\begin{array}{l}\text { We have a real passion for continually changing the way products (goods /services) } \\
\text { are marketed in our business }\end{array}$ & & & & & \\
\hline 02 & $\begin{array}{l}\text { Our business is frequently one of the first in the business community to alter its } \\
\text { marketing methods. }\end{array}$ & & & & & \\
\hline 03 & We consistently monitor and improve the approach to marketing our business. & & & & & \\
\hline 04 & We constantly lookout for new ways to improve our business enterprise & & & & & \\
\hline 05 & In our business enterprise, we enjoy overcoming obstacles to our business ideas & & & & & \\
\hline 06 & We are good at turning problems at our business enterprise into opportunities & & & & & \\
\hline 07 & We are good at identifying opportunities for our business enterprise. & & & & & \\
\hline 08 & $\begin{array}{l}\text { In our business enterprise, it is more exciting to see our business ideas turn into } \\
\text { reality. }\end{array}$ & & & & & \\
\hline & B) Risk Management (Q9-Q12) & 1 & 2 & 3 & 4 & 5 \\
\hline 09 & $\begin{array}{l}\text { When we decide to pursue a new marketing direction, we do so in stages rather } \\
\text { than all at once to reduce the risk involved }\end{array}$ & & & & & \\
\hline 10 & $\begin{array}{l}\text { Our business typically uses creative, low cost ways to reduce risks associated with } \\
\text { new marketing activities }\end{array}$ & & & & & \\
\hline 11 & Our business enterprise is willing to take risks for benefits of the company & & & & & \\
\hline
\end{tabular}




\begin{tabular}{|c|c|c|c|c|c|c|}
\hline 12 & Our business enterprise would not be considered gamblers, but we do take risks & & & & & \\
\hline & C) Opportunity driven (Q13-Q17) & 1 & 2 & 3 & 4 & 5 \\
\hline 13 & When new market opportunities arise, Our business very quickly acts on them. & & & & & \\
\hline 14 & Our business excels at identifying marketing opportunities. & & & & & \\
\hline 15 & $\begin{array}{l}\text { Management approach looks beyond current customers or current market for more } \\
\text { business opportunities for our business. }\end{array}$ & & & & & \\
\hline 16 & Our business enterprise is always looking for new opportunities & & & & & \\
\hline 17 & Our business enterprise will do whatever it takes to pursue a new opportunity & & & & & \\
\hline & D) Innovativeness ( Q18-Q23) & 1 & 2 & 3 & 4 & 5 \\
\hline 18 & Communicating with customers is a great way to identify innovation opportunities & & & & & \\
\hline 19 & Innovation is the key to achieving competitive advantage in our business. & & & & & \\
\hline 20 & Our business enterprise tends to be more innovative than most of competitors & & & & & \\
\hline 21 & Our staff contributes a lot of ideas to innovations undertaken by our business & & & & & \\
\hline 22 & $\begin{array}{l}\text { Our business enterprise tries to use innovative approaches for getting the job done } \\
\text { efficiently }\end{array}$ & & & & & \\
\hline 23 & Our business enterprise creates an atmosphere that encourages innovativeness & & & & & \\
\hline & E) Resource leveraging ( Q24-Q30) & 1 & 2 & 3 & 4 & 5 \\
\hline 24 & $\begin{array}{l}\text { Our Business enterprise has always found a way to get the resources need to get } \\
\text { the job done }\end{array}$ & & & & & \\
\hline 25 & Our Business enterprise prides itself on doing more with less & & & & & \\
\hline 26 & $\begin{array}{l}\text { Our Business enterprise has used networking to get advantage in favor of our } \\
\text { enterprise(with customers, suppliers, banks and retailers etc.) }\end{array}$ & & & & & \\
\hline 27 & $\begin{array}{l}\text { Our business is good at complementing or blending of one resource with another } \\
\text { resource to create a greater combined value }\end{array}$ & & & & & \\
\hline 28 & We use existing resources to control other resources in our business & & & & & \\
\hline 29 & We use certain resources to obtain other resources & & & & & \\
\hline \multirow[t]{2}{*}{30} & $\begin{array}{l}\text { We use the resources of other people or companies to accomplish one's own } \\
\text { purpose by contracting, outsourcing, joint ventures or sharing }\end{array}$ & & & & & \\
\hline & F) Customer intensity (Q 31- Q 37) & 1 & 2 & 3 & 4 & 5 \\
\hline
\end{tabular}




\begin{tabular}{|c|c|c|c|c|c|c|}
\hline 31 & $\begin{array}{l}\text { Our business creates solid relationships with customers through its marketing } \\
\text { efforts }\end{array}$ & & & & & \\
\hline 32 & $\begin{array}{l}\text { We spend considerable resources continually trying to learn more about each of our } \\
\text { customers }\end{array}$ & & & & & \\
\hline 33 & Our business enterprise frequently measures our customer satisfaction & & & & & \\
\hline 34 & $\begin{array}{l}\text { All employees in our enterprise recognize the importance of satisfying our } \\
\text { customers }\end{array}$ & & & & & \\
\hline 35 & Our business enterprise objectives are driven by customer satisfaction & & & & & \\
\hline 36 & Our business enterprise pays close attention to after-sales services & & & & & \\
\hline 37 & $\begin{array}{l}\text { Our business enterprise closely monitors and evaluates our level of commitment in } \\
\text { serving customers' needs. }\end{array}$ & & & & & \\
\hline & G) Value creation (Q 37-Q 44) & 1 & 2 & 3 & 4 & 5 \\
\hline 38 & $\begin{array}{l}\text { We expect every employee to be looking for ways our business can create more } \\
\text { value for customers. }\end{array}$ & & & & & \\
\hline 39 & In our business, employees contribute to ideas to create value for customers & & & & & \\
\hline 40 & Our enterprise creates value for consumers with excellent customer service. & & & & & \\
\hline 41 & Our enterprise's pricing structure is designed to reflect value created for customers & & & & & \\
\hline 42 & Our enterprise's pricing structure is appropriate to create value to customers. & & & & & \\
\hline 43 & Providing value for our customers is the most important thing of our enterprise. & & & & & \\
\hline 44 & We integrate enterprise functions to better serve the target market needs & & & & & \\
\hline
\end{tabular}

